„Kwartalnik Filmowy” nr 109 (2020)

ISSN: 0452-9502 (Print) ISSN: 2719-2725 (Online)

https://doi.org/10.36744/kf.266

(c) Creative Commons BY-NG-ND 4.0

\title{
Rafał Koschany
}

Uniwersytet im. Adama Mickiewicza

http://orcid.org/oooo-0oo2-9343-9885

\section{Architektura jako fabuła. O Parasite Bong Joon-ho}

\author{
Slowa kluczowe: \\ Bong Joon-ho; \\ kino koreańskie; \\ architektura; \\ narracja filmowa; \\ przestrzeń \\ filmowa
}

\begin{abstract}
Abstrakt
Film Parasite Bonga to jedna z częściej nagradzanych i najlepiej ocenianych przez recenzentów premier 2019 r. Większość dziennikarzy podkreślała w swych opiniach krytyczny i satyryczny wydźwięk utworu wymierzony przeciw rozwarstwieniu ekonomicznemu społeczeństwa Korei Południowej (i nie tylko). W proponowanej interpretacji jest jednak zaakcentowany zupełnie inny wymiar filmu, zasygnalizowany w tytułowej formule „architektura jako fabuła”. Artykuł składa się z trzech części. Częśś pierwsza obejmuje wstępne ustalenia teoretyczne związane z kategorią przestrzeni filmowej oraz relacją miasta (architektury) i filmu. Część druga to analiza semiotyki miasta oraz architektury domu, w którym rozgrywa się większa część akcji. Ostatnia część jest poświęcona rozważaniom na temat architektury jako generatora kolejnych zdarzeń, które ostatecznie można interpretować jako rodzaj udawania na scenie bądź gry planszowej. W ramach konkluzji pojawia się propozycja, by ostatecznie potraktować film Bonga jako wypowiedź autotematyczną, której precyzyjna struktura jest nie tyle celem, ile tematem.
\end{abstract}


Przed piszącym o filmie Parasite (2019) Bong Joon-ho stoją dwie zasadnicze trudności. Pierwsza dotyczy koniecznego wprowadzenia w fabułę, zwłaszcza gdy propozycja interpretacji - jak niniejsza - w dużym stopniu opiera się na relacjach interpersonalnych, omyłkach, zwrotach akcji. Bezpiecznie zarysowany układ powiązań między postaciami - od razu sygnalizujący strukturalistyczne myślenie reżysera - przedstawia się zatem następująco. W biednej dzielnicy wielkiego miasta Korei Południowej żyje czteroosobowa rodzina państwa Kim: Ki-taek (były kierowca), Chung-sook (była kulomiotka) oraz ich dorosłe dzieci - córka Ki-jeong i syn Ki-woo. Żyją w ciasnym piwnicznym mieszkaniu, są bezrobotni, ale zaradni i ambitni. Z kolei na przedmieściach stoi ogromny dom państwa Park: Dong-ik (czyli Mr Park, zajmujący wysokie stanowisko w firmie produkującej sprzęt IT), Yeon-kyo (Mrs. Park, niepracująca żona) i dwójka dzieci: nastoletnia Da-hye oraz kilkulatek Da-song. Domem zajmuje się gosposia - Moon-gwang. Pewnego dnia zdolny Ki-woo, który nie dostał się na wymarzone studia, zostaje poproszony przez wyjeżdżającego na stypendium przyjaciela o zastępstwo w udzielaniu prywatnych lekcji języka angielskiego córce zamożnego małżeństwa. Już pierwsze spotkanie z państwem Park inspiruje chłopaka do wprowadzenia w życie planu: odtąd kolejni członkowie rodziny Kim podstępem (i jako obce sobie osoby) znajdują zatrudnienie w willi bogaczy.

Trudność druga jest związana z przesytem interpretacyjnym. Parasite w prasie branżowej oraz na portalach filmowych i blogach internetowych został już omówiony na wszystkie możliwe sposoby ${ }^{1}$, a przyczyny tego fenomenu aktywności krytycznej i analitycznej zostaną wyjaśnione, mam nadzieję, w dalszych partiach tekstu. Motywem przeważającym $\mathrm{w}$ tych próbach jest kwestia rozwarstwienia ekonomicznego współczesnego społeczeństwa (nie tylko) koreańskiego. Wskazywany jednak przez krytyków w tym kontekście metaforyczny wymiar dzieła jest oczywisty tylko z pozoru. Zwłaszcza doszukiwanie się znaczeń tytułu wydaje się niekonkluzywne, bowiem oprócz ewidentnego skojarzenia nieuprzywilejowanych warstw społeczeństwa z karaluchami dodatkowo pojawia się tutaj przecież motyw walk wewnątrzklasowych (klan Kimów vs. klan Moon-gwang, czyli byłej gosposi bogatych gospodarzy i jej męża), a także relacja odwrotna (wymownym przykładem jest scena, gdy służąca budzi drzemiącą panią Park klaśnięciem w dłonie).

Te symetrycznie ułożone tropy pozwalają stwierdzić, z jednej strony, że semiotyczny i aksjologiczny wymiar filmu nie jest jednoznaczny i w kompromisowy sposób wyważony, z drugiej zaś - co może ważniejsze - że jednocześnie jest on od początku podawany w wątpliwość. Mianowicie w dialogach filmowych kilka razy pojawia się stwierdzenie o „metaforyczności” jakiegoś znaku bądź przekazu - oto jawny sygnał reżyserskiej ironii i podpowiedź, by nie traktować żadnego z możliwych przesłań zbyt serio (nawet jeśli piwnica domu, a pod nią jeszcze głębiej ukryty schron będą się domagać "głębinowej” interpretacji). Podobnie działają tu elementy magiczne czy baśniowe, obecne bądź pod postacią tajemniczego kamienia, który trafia do rodziny Kim, by zapewnić jej bogactwo, bądź też zjawisk pogodowych (z piorunami i potopem włącznie), dopasowanych do zdarzeń i wypowiadanych słów.

Bong Joon-ho, reżyser takich filmów, jak Zagadka zbrodni (Salinui chueok, 2003), The Host: Potwór (Goi-mool, 2006), Matka (Ma-deo, 2009), Snowpiercer (2013) czy Okja (2017), jest uważany za jednego ze współczesnych mistrzów opowiadania historii. W Parasite zaś tematyzowany jest sam proces opowiadania (récit). Udaje się to w dużej mierze dzięki uwypukleniu w scenariuszu roli architektury. Pomijając zatem aspekty społeczno-ekonomiczne w odczytaniu dzieła, chcę zaproponować interpretację skupiającą się na tajemniczym domu, w którym rozgrywa się główna część akcji opowieści i dzięki któremu, jeśli można tak powiedzieć, owa akcja się rozgrywa. 


\section{Film - przestrzeń - architektura}

W nurcie intersemiotycznej refleksji nad związkami filmu i architektury najczęściej pojawiają się propozycje porządkowania tego zagadnienia w dwóch kierunkach, zgodnie z nadrzędnymi pytaniami: $w$ jaki sposób film (konkretny, ale także sztuka filmowa w ogóle) oddziałuje na architekturę oraz w jaki sposób architektura (poszczególne realizacje, ale także szerzej: rodzaj wyobraźni architektonicznej) jest wykorzystywana w sztuce filmowej? Odpowiedzi są tu o wiele trudniejsze niż w przypadkach intersemiotycznych translacji, czyli w próbach przekładów danego dzieła sztuki czy tekstu kultury na jego ekwiwalent proponowany w innym ,języku", by poprzestać na najbardziej oczywistym w tym kontekście przykładzie adaptacji.

Odnośnie do pierwszego z zasygnalizowanych kierunków, w interpretowanych praktykach artystycznych i urbanistycznych szczególnie interesujący wydaje się styl "filmowego" projektowania architektonicznego, a także szersza tendencja $\mathrm{w}$ rozwoju miast i myślenia o mieście. Nie jest to obszar badań eksplorowany zbyt często, jednakże w XX-wiecznej historii architektury zdarzały się projekty lub nawet realizacje tak mocno zanurzone w kulturze filmowej albo tak wyraźnie inspirujące się filmoznawczo-filozoficznymi teoriami, że nie sposób ich tutaj pominać. Bodaj najsłynniejszymi przykładami takiej „kinematyzacji” w projektowaniu są realizacje - właściwie pionierskie w tym kontekście - Bernarda Tschumiego, autora między innymi słynnego Parc de la Villette w Paryżu, określanego czasem „filmem architektonicznym" ${ }^{\prime 2}$.

Natomiast w kontekście szerzej rozumianych tendencji „ufilmowienia” miast trzeba wziąć pod uwagę między innymi nasycenie przestrzeni „miejskimi ekranami”, jak to określiła Ewa Rewers ${ }^{3}$, ale też tak radykalne projekty artystyczne, jak The Stairs 2: Projection Petera Greenawaya z cyklu The Stages, w którym architektura Monachium stała się ekranem projekcji filmowych (Andrzej Gwóźdź umieścił tę realizację w ramach tendencji nazwanej „hybrydyzowaniem kina i architektury" $\left.{ }^{4}\right)$, czy koncepcje „pejzażu miejskiego" Wima Wendersa ${ }^{5}$. Jak pisze przywoływana badaczka: Stosunek do eklektycznej przestrzeni, doświadczenie sfragmentaryzowanego czasu, kondensacja różnic, poczucie odmienności i wykorzenienia, czy przemieszanie się tego, co marginalne, z tym, co centralne, indywidualnych styków życia z masową konsumpcja, można uznać w równym stopniu za cechy kultury filmowej oraz przestrzeni miejskiej6.

W przypadku drugim, kiedy mowa o obecności architektury w filmie, znacznie częściej pojawiają się wizualne nawiązania do konkretnych realizacji oraz, rzecz jasna, interpretacje tych nawiązań. Trudno nie wspomnieć tu o odmianie dokumentu, która wyspecjalizowała się w filmowaniu architektury (konkretnych budynków, miast, biografii słynnych architektów etc.) i której są poświęcone osobne festiwale i nagrody. Również w filmie fabularnym architektura - tak jak i przestrzeń - jest nierzadko czymś więcej niż tylko tłem akcji. W konsekwencji wszelkie „filmowe portrety" $i$ „reprezentacje” miast to pretekst zarówno do analiz historyczno-kulturoznawczych ${ }^{7}$ oraz kinofilskich eksploracji (od turystyki filmowej ${ }^{8}$ po zjawisko zwane set-jettingiem ${ }^{9}$ ), jak i praktyk oraz badań z zakresu city-placement ${ }^{10}$.

Pozostawiam jednakże wspomniane tu tendencje transferu (oraz podążające za nimi teorie) na marginesie, bowiem w kontekście zaproponowanej w tytule formuły ważniejszy wydaje się trzeci obszar praktyk artystycznych i poszukiwań teoretycznych (z jedoczesnym zastrzeżeniem, że - zarówno na poziomie projektowania, jak i późniejszych analiz - nie zawsze udaje się go oddzielić od pierwszego i/lub drugiego obszaru czy kierunku). Chodziłoby tu mianowicie o próby wskazania - niezależnie od wektora ekwiwalencji - wspólnych 
mianowników dla kina i architektury, wśród których najczęściej są wymieniane: samo pojęcie przestrzeni ${ }^{11}$, podobne (lub przynoszące podobne doznania) doświadczenie kinestetyczne ${ }^{12}$, zdolność tworzenia iluzji, a także - co w propozycji interpretacyjnej filmu Parasite okazuje się kluczowe - powinowactwa semiotyczne oraz strukturalne ${ }^{13}$.

\section{Semiotyzacja przestrzeni}

Na pozór wszystkie relacje przestrzenne oraz funkcje architektury w Parasite są jawne, oczywiste albo - odwracając wypowiadane dość często przez młodego Ki-taeka To takie metaforyczne! - z gruntu niemetaforyczne, tak że właściwie nie domagają się interpretacji. Klarowny jest więc podział na ubogie, gwarne i intrygujące dzielnice oraz zamożne i spokojne, ale jednocześnie mało interesujące przedmieścia; podział na doły (sutereny, piwnice, kanały) i góry (wille-twierdze otoczone murami) oraz odpowiadające im symbole; wreszcie podział na biednych i bogatych, zależnych i uprzywilejowanych, „niewolników” i „panów”. W wielkim skrócie i zgodnie z filmową reprezentacją mamy tu do czynienia z karaluchami i rasowymi pieskami. Pasują tu też wykładnie powszechnie znane ze słowników symboli, zgodnie z którymi w symbolice domu piwnica odpowiada nieświadomości i instynktom (jak ścieki w mieście) ${ }^{14}$.

Z owego „na pozór” trzeba jednakże uczynić główne zastrzeżenie interpretacyjne, wskutek czego mniej ważne okazują się znaczenia i polaryzacje same w sobie, bardziej zaś - tak ostentacyjna gra nimi. Jedno z istotnych założeń niniejszego szkicu stanowi zatem przekonanie, że w rysowaniu przez reżysera takich relacji wyraźne binaryzmy czy skrajności pojawiają się po to, aby ich skrzyżowanie było tym bardziej ostentacyjne i ni emetaforyczne.

W przypadku Parasite nadrzędnym kontekstem dla filmowego systemu znaków i relacji jest miasto i jego wyeksponowana struktura. Właściwie od pierwszego ujęcia widz jest przekonywany, że jednym z bohaterów filmu będzie przestrzeń i jej wartości symboliczne: oto znaczące pozycjonowanie punktu widzenia, czyli perspektywa mieszkańców piwnicznego lokalu, którego okno wystaje tylko trochę nad ulicę (ściśle rzecz biorąc, chodzi o suterenę, co jest istotne w kontekście wyznaczania kolejnych warstw przestrzennych filmu oraz przynależności i aspiracji jego bohaterów). Tu jest uliczny gwar, wszystko się ze sobą miesza: dźwięki, zapachy, włącznie z oparami miejskiej dezynsekcji. W ten sposób żyje rodzina państwa Kim. Cała czwórka para się dorywczymi zleceniami oraz, mówiąc wprost, kombinuje, jak się podpiąć do darmowego Internetu, a może nawet i osiągnąć sukces... Niebawem, z racji zawrotnego tempa rozwoju wypadków oraz - co stanie się jeszcze jaśniejsze w kontekście wzmiankowanych $\mathrm{w}$ dalszej części tekstu gatunkowych inspiracji Bonga - w wyniku zbiegu okoliczności, młodzieniec Kim zmierza do swych przyszłych pracodawców, państwa Park. Na wybrukowanym wzgórzu podmiejskiej bogatej dzielnicy mieści się ich okazały, otoczony murem dom z własnym systemem kamer i zabezpieczeń. Zbudowany w ten sposób kontrast ujawnia się w całej pełni nieco później, podczas (pierwszej) ucieczki Ki-taeka i dzieci z „okupowanej” willi do sutereny (po nieoczekiwanie szybkim powrocie rodziny Park z biwaku). Uzyskujemy w tej scenie pełną perspektywę na miasto - jego wszystkie wzniesienia i zagłębienia, plątaninę schodów (skojarzenie z Giovannim Battistą Piranesim nie będzie chyba przesadą), sieci kabli i instalacji, a także ściekającą z dachów, ścian i schodów wodę niosącą dodatkowe warstwy symboliczne: kataklizmu i zmywanego brudu, kary i odkupienia win. Taki język opisu miasta jest oczywiście tylko jedną z możliwości, jednakże nie należy pomijać faktu, że właśnie semiotycznych analiz domagają się systemy szczególnie wyraziste i znaczące ${ }^{15}$. 
Dom - jako szczególnie istotny bohater tego szkicu - oraz jego usytuowanie i ustrukturyzowanie prowokują do dalszych eksploracji semiotycznych. Najpierw otwierają się wszelkie możliwe asocjacje historycznofilmowe. Ten rodzaj domu, a zwłaszcza jego uwarunkowania architektoniczne, to przecież często miejsce akcji thrillerów lub horrorów ${ }^{16}$, by przywołać najbardziej znany przykład, czyli Psychoze (Psycho, 1960) Alfreda Hitchcocka. Na szczególną uwagę zwraca jednak kontekst dla filmu macierzysty. W swej recenzji Parasite Łukasz Mańkowski umieszcza kwestię architektury i symboliki domu państwa Park w historii kina koreańskiego oraz dość typowego, jak się okazuje, dla niego motywu. Bowiem kluczową rolę - oprócz samej struktury domu jako miejsca akcji - odgrywa w filmie Bonga postać, a właściwie typ służącej, odsyłający choćby do słynnego tryptyku Ki-young Kima: Pokojówka (Hanyo, 1960), Kobieta z ognia (Hwa-nyeo, 1971) i Kobieta-owad / Modliszka (Chungyo, 1972). Reżyser zresztą wielokrotnie sam się przyznawał do inspiracji twórczością tego klasyka rodzimego kina. Autor recenzji pisze: Tak jak w "Pokojówce” reprezentant klasy wyższej staje się niewolnikiem erotycznej gry, tak bogata rodzina w "Parasite” poddaje się urokowi wyjątkowo utalentowanych oszustów, rodziny, której "referencje” wyjątkowo odpowiadaja najdziwniejszym wymaganiom bogatych; w efekcie stają się oni niewolnikami własnych klasowych przyzwy$c z_{a j e n}{ }^{17}$. Jak przekonuje Mańkowski, w każdym z przywoływanych filmów poziomowe rozplanowanie domu okazywało się kluczowe zarówno dla sensu opowieści, jak i sposobu prowadzenia narracji.

Jaki zatem jest dom państwa Park? Przede wszystkim ma swoją historię opowiedzianą w filmie. Zaprojektował go (a potem w nim mieszkał) słynny architekt Namgoong, jak to przedstawia jego dawna gosposia, będąca swoistym łącznikiem między starym a nowym, między historią a teraźniejszością, wreszcie między widzialnym a ukrytym. Architekt fikcyjny, co warto dodać i co wymaga dodatkowego komentarza do kwestii związanych z realizacją filmu. Bowiem cały dom, wraz z przylegającym ogrodem, to zbudowana na potrzeby dzieła scenografia. Jak mówi jej autor, Ha-jun Lee: Myśleliśmy o przestrzeni jako o innym aktorze ${ }^{18}$. Zaprojektowane zostały więc wszystkie strukturalne uwarunkowania techniczne, które ostatecznie ujawniają się w filmie czy to jako szczegóły konstrukcyjne domu, czy też w sposobach poruszania się po nim: piętro, parter, piwnica, schron; schody pomiędzy tymi poziomami, poziome trajektorie ruchu postaci w parterowej, głównej części domu; przestrzenne i wzajemne relacje pomiędzy tą częścią a ogrodem. W cytowanym wywiadzie reżyser podkreślał, że dom został zaprojektowany i funkcjonował w filmie jako „własny wszechświat”.

Z jednej strony uzyskany na ekranie efekt daje się interpretować jako Łotmanowska „przestrzeń artystyczna” - skończona w ramach tekstu (filmu) i ustalająca dla niego reguły funkcjonowania wszystkich elementów owej przestrzeni: przestrzeń artystyczna nie jest jakimś obojętnym miejscem dla bohaterów i epizodów fabularnych. Jej związek z postaciami i formowanym przez tekst artystyczny ogólnym modelem świata przekonuje, iż język przestrzeni artystycznej nie jest nieznaczacy, lecz stanowi jeden z komponentów ogólnego języka, jakim przemawia przekaz artystyczny ${ }^{19}$. Podobnie charakteryzował Łotman przestrzeń w swojej Semiotyce filmu: przestrzeń $w$ kinie - jak i w każdej sztuce - jest przestrzeniq odgraniczona, zamknięta w określonych ramach, a jednocześnie jest izomorficzna wobec bezgranicznej przestrzeni świata rzeczywistego ${ }^{20}$. To w tej (semiotycznej) tradycji można rozpatrywać wszelkie „znaczące”, jak schody, piwnica czy schron, a także relacje, przede wszystkim o paralelnym, binarnym bądź antytetycznym charakterze: góra - dół, wnętrze - zewnętrze, zamknięte - otwarte, widzialne - niewidzialne, jawne - ukryte etc. Inaczej mówiąc, sensy i wartości, które z taką oczywistością wydają się przydane poszczególnym przestrzeniom i poruszającym się $\mathrm{w}$ nich postaciom, nie mają znaczenia samoistnego, lecz systemowe: znaczą przez zestawienie z przestrzenią kontras- 
tująca, z jej negatywem lub zaprzeczeniem. Piwniczne mieszkanie Kimów nie niosłoby aż tak wyraźnych konotacji z insektami czy odorem pleśni, gdyby nie ustawienie go w relacji z umieszczonym na wzgórzu, antyseptycznym domem Parków. Następnie, reprezentacyjna część domu Parków nie kojarzyłaby się z wyzyskiem, hipokryzja, obłuda, ignorancją czy naiwnością właścicieli, gdyby nie jej zestawienie z podziemnym schronem przedstawianym jako tajemnicza przestrzeń cierpienia i okrucieństwa.

Jednakże z drugiej strony dom państwa Park i film Parasite w ogóle to coś znacznie więcej niż pretekst do rozważań o „przestrzeni artystycznej”. Jurij Łotman pisał przecież, że problemy semiotyczne zaczynaja wnikać nie tylko do języka, ale i do treści taśm filmowych ${ }^{21}$ i na przykładzie Powiększenia Antonioniego udowadniał, jak dochodzi do takiej tematyzacji (semiotyka jako temat filmu) i samozwrotności (film o istocie filmu, fotografii, obrazu itd.): Reżyser upewnia widzów o tym, że życie należy rozszyfrowywać22. W tym momencie można się już pokusić o wskazanie swego rodzaju analogii i stwierdzić, że także Bong Joon-ho w Parasite tematyzuje - tym razem jednak sam proces opowiadania.

\section{Narratywizacja architektury}

W teoriach przestrzeni filmowej można znaleźć próby periodyzacji i typologizacji obecności tej kategorii jako twórczo wykorzystywanego elementu w procesie opowiadania. I tak na przykład Tadeusz Miczka przypomina - za Jerzym Płażewskim - że dopiero na jednym z etapów rozwoju kina (trzecim, po okresach teatralnego i montażowego ujmowania przestrzeni) przestrzeń uzyskała samodzielne walory dramatyczne ${ }^{23}$. Z kolei Elżbieta Ostrowska w autorskim opracowaniu interesującego mnie zagadnienia wyróżnia dwa zasadnicze modele przestrzeni filmowej: nieznarratywizowaną oraz znarratywizowaną. W przypadku tej ostatniej kolejne segmenty przestrzeni filmowej zostaja skrajnie podporzadkowane względom narracyjnym, a tym samym przeksztatcone w "miejsce akcji” opowiadanej historii ${ }^{24}$ głównie w kinie hollywoodzkim czy też, zgodnie z typologią Davida Bordwella, w modelu narracji klasycznej.

Dom państwa Park jest zatem centralną i znaczącą przestrzenią filmu czy, jak przyznali sami twórcy, jego bohaterem i głównym aktorem. To tutaj rozgrywa się większa część akcji, w tym jej kluczowe zdarzenia. Co więcej, w filmie zostaje opowiedziana jego historia i po kolei są odsłaniane tajemnice, które uruchamiają dalsze perypetie rodziny Kim, państwa Park oraz byłej gosposi Moon-gwang i jej męża. Przede wszystkim jednak dom ten pełni funkcję koła zamachowego akcji oraz - by tak rzec - szkieletu architektonicznego opowieści, czyli sekwencji zdarzeń prowadzących wprost do tragicznego finału.

W efekcie analizy podstawowych zależności między przestrzenią a ruchem postaci (oraz - szerzej - wszelkim dzianiem się) można stwierdzić, że sam sposób filmowania układu domu i poruszających się w nim bohaterów podkreśla linie proste: poziome, pionowe oraz skośne (zgodnie z kierunkiem schodów). Schody łączące parter i piętro oglądamy zwykle w ujęciu panoramicznym, niejako „z profilu”, a ruch postaci - po skosie - jest tu w pełni widoczny dopiero ze znacznej odległości, pozwalającej obserwować maksymalną powierzchnię salonu, holu, kuchni i schodów właśnie. Z kolei stopnie między parterem a piwnicą są ukazywane zazwyczaj z góry, natomiast ukryte schody do schronu, połączone z labiryntowymi przejściami, są często filmowane z perspektywy poruszającej się po nich postaci. W ten sposób widz zostaje wprowadzony w tajemnicę domu, z czasem także w gatunkowe zabawy z konwencjami chociażby thrillera i horroru.

Skonstruowany i zmontowany tu system poruszania się - wchodzenia i schodzenia, przesuwania w prawo i w lewo, do przodu i w głąb - to, po pierwsze, ruch w czystej postaci 
(istota filmowości, jak powiedziałby Irzykowski²5). Linie ruchu podlegają częstemu kontrastowaniu: pionowe krzyżują się z poziomymi, jak podczas pierwszych wizyt młodego Ki-woo w domu: kiedy pani Park prowadzi go po schodach w górę, w tym samym czasie gosposia przechodzi przez parter. Do tego dochodzą jazdy kamery, na przykład ruch wertykalny postaci jest skontrastowany z poziomym odjazdem kamery. Wszystko układa się w precyzyjny wzór. Jak przekonuje w wywiadach scenograf, Bong już na etapie scenariusza miał zaplanowany rozkład „ścieżek”, po których mieli się poruszać aktorzy w domu skonstruowanym na potrzeby filmu ${ }^{26}$. Tak jak architekci projektują domy dla konkretnych ludzi mających w nich zamieszkać, tak w przypadku konstrukcji scenograficznej w Parasite dom został pomyślany wokół ścieżek, tras i wzorów, według których ludzie mają się poruszaćén.

Po drugie - także w ujęciu logiki przyczynowo-skutkowej - każdy ruch postaci generuje kolejne zdarzenie fabularne. Poruszanie się bohaterów w przestrzeni domu nie jest motywowane zasadami kinezyki czy behawiorystyki (chociaż każdy z nich to świetnie napisany i zagrany "typ"), lecz dyktowane fabułą. Traktując rzecz w ogromnym skrócie: samo schodzenie i wchodzenie po schodach zmienia się w system wiązania poszczególnych elementów tej fabuły. Podobnie ruch jest rozrysowany nawet w obrębie tego samego pomieszczenia, na przykład kiedy ukrywająca się rodzina leży pod stołem (podczas gdy państwo Park spędzają na kanapie obok - i powyżej - noc erotycznych uniesień), a potem - dosłownie w poziomie, czołgając się po podłodze - spod niego ucieka. Tak jakby architektura permanentnie prowadziła akcję, stawała się jej katalizatorem.

Sformułowanie „architektura jako fabuła” jest oczywiście pewnym uproszczeniem, by nie powiedzieć: chwytem retorycznym. W owym chwycie mieści się dość oczywista analogia: tak jak architektura (konkretne realizacje architektoniczne) to swego rodzaju materialne podłoże przestrzeni (filmowej), tak fabuła jest - również istniejącym w sposób obiektywny, "materialny” - budulcem narracji (filmowej). Zastosowana w ten sposób konstrukcjonistyczna (z jednej strony) oraz strukturalistyczna (z drugiej) metoda analizy pozwala spojrzeć również na przywoływane wcześniej epizody w takim właśnie ujęciu; jednakże kluczowe i obrazowo oddające istotę rzeczy wydają się tu dwie przestrzenie i przyporządkowane im zdarzenia.

Najistotniejsze funkcje z punktu widzenia prowadzonej narracji pełni piwniczna przestrzeń prowadząca do schronu. Wejście do niego mieści się za przesuwaną szafa, co „otwiera" także system baśniowych skojarzeń, w ramach których zawiera się istnienie ukrytego przed światem sejfu, sezamu. By dostać się do środka, potrzebny jest klucz, wiedza tajemna i dostępna wybranym. W przeciwnym wypadku czar pryska i tajemnica mści się na niepowołanych do jej poznania bohaterach. $W$ ten właśnie sposób filmowy schron, długo ukrywany i funkcjonujący jako tajemnica starej gosposi ukrywającej w nim męża, zdradza swój sekret, przechodzi z rąk do rąk, a przede wszystkim w kluczowych momentach filmu napędza akcję; zmienia jej kierunek, a także - co najciekawsze - „swoich” bohaterów.

Kolejne sprzężenie przestrzeni domu oraz tym razem jednego, konkretnego zdarzenia zachodzi w kulminacyjnej scenie filmu, podczas ucieczki Ki-taeka. Scenę tę poprzedza przyjęcie ogrodowe wyprawione dla synka państwa Park. Zebrali się już wszyscy goście, przygrywają muzycy, w zaroślach czają się ojciec jubilata i jego kierowca w indiańskich przebraniach, aby - podczas przygotowanej zabawy - zaatakować nadchodzącą z tortem Ki-jeong. Niespodziewanie na scenę w kracza, po zwycięskiej walce stoczonej z Ki-woo, uwolniony z piwnicznych mroków mąż byłej gosposi. Godzi nożem pannę Kim i odtąd wszystko toczy się w zaskakującym kierunku i błyskawicznym tempie. Interesująca mnie sekwencja zdarzeń jest następująca: podczas gdy ojciec opiekuje się ranioną córka, pan Park próbuje wyciągnąć spod ciała męża Moon-gwang (zabitego wcześniej przez panią 
Kim) kluczyki od samochodu. Słysząc jego słowa i widząc reakcję na odór wydzielany przez ciało (jeden z wielu lejtmotywów w filmie), Ki-taek pozostawia córkę i zabija gospodarza. Ucieka - i właśnie ten moment wydaje się najbardziej charakterystyczny dla omawianej zasady, w ramach której przestrzeń (architektura) determinuje bieg zdarzeń, staje się niejako ciągiem dalszym i/lub (tymczasowym) rozwiązaniem problemu.

Przebieg ucieczki Kima obserwujemy - jako widzowie - w trzech wersjach. W czasie rzeczywistym jest ona filmowana z góry, jakby przestrzeń domu i ogrodu stała się nagle grą komputerową lub planszową: zmęczony bohater biegnie, aż nagle skręca i chowa się w garażu. Z kolei w wiadomościach telewizyjnych relacjonujących tę ucieczkę dokonano jej prawdopodobnej rekonstrukcji: przedstawiono okolice domu, wszystkie wejścia, wyjścia, schody, ścieżki itd. (była gosposia zdążyła wcześniej unieruchomić kamerę monitorującą posesję). Wreszcie w ostatniej wersji o szczegółach ucieczki usłyszymy od samego bohatera, któremu po długim czasie udało się przekazać synowi - za pomocą alfabetu Morse'a - wiadomość. To w niej została wyjaśniona zasada „architektury jako fabuły” - podczas ucieczki bohater doznał swego rodzaju olśnienia i został niejako poprowadzony do schronu.

Warto zaznaczyć, że większość tak charakteryzowanych zdarzeń filmowych, jako zdarzeń ściśle skorelowanych z architekturą domu, sugeruje bardzo wyraźne nawiązania do konkretnych gatunków filmowych, a co za tym idzie - do funkcjonującej w ich uniwersach przestrzeni, z jej wymiarem fizykalnym i semiotycznym. Oprócz wspomnianego już horroru i thrillera w kontekście interpretacji architektonicznej szczególnie interesujące są rozwiązania o rodowodzie komediowym, przede wszystkim inspiracje slapstickiem (ktoś ucieka, ktoś się chowa, ktoś kogoś podgląda, ktoś się potyka, spada ze schodów i tak dalej) czy klasyczna, odsyłającą do tradycji teatralnej komedią omyłek (opartą między innymi na inicjowaniu kolejnych intryg; tu symptomatyczna jest scena, kiedy Kim odbiera SMS od, jak ją określił w kontaktach telefonicznych, „pani domu”: Drugie piętro, pokój z sauna). Oryginalność Parasite nie wynika z tego, że film opiera się na takich chwytach, ale z konsekwentnego podporządkowania zdarzeń architekturze. Kolejne epizody następują właśnie dlatego, że takie, a nie inne jest ich usytuowanie przestrzenne.

Rozważania te prowadzą do dwóch - skorelowanych ze sobą - konkluzji interpretacyjnych, sugerowanych już zresztą w toku wywodu. Otóż relacja architektury i fabuły, zastosowane $\mathrm{w}$ jej ramach rozwiązania techniczne, a także wykonanie aktorskie (na przykład w zakresie ruchu postaci i dzięki nawiązaniom do konwencji slapstickowej) pozwalają widzieć filmowy dom jako scenę. Najpierw nasuwają to skojarzenie poszczególne zdarzenia i wypowiedzi postaci dotyczące gry, udawania, aktorstwa: siostra chłopca jest przekonana, że ten udaje artystę; przed pozbyciem się gosposi rodzina Kimów przeprowadza "prawdziwe" próby a ktorskie; podczas rodzinnej biesiady Kimów w domu gospodarzy Chung-sook naigrawa się z męża, na co ten reaguje agresja, jak się za moment okaże w konwencji żartu; dawna służąca, wyzwolona na chwilę z piwnicy, od gry wa „polityczne" przemówienie w stylu przywódcy Korei Północnej; w scenie erotycznej państwa Park pojawia się chęć odgrywania kogoś innego (zresztą ta scena jest zaszyfrowana podwójnie: $\mathrm{z}$ jednej strony małżonkowie udają kogoś, kim w codziennym życiu nie sa, z drugiej zaś - być może w sytuacji chwilowej utraty kontroli - prawda wychodzi na jaw); wreszcie budzący się do życia po operacji mózgu Ki-woo zauważa, że stojący przed nim detektyw nie wygląda na detektywa, a lekarz na lekarza.

Oprócz tematyzowanego w ten sposób motywu gry i udawania pojawiają się także - wzmacniające podobną wykładnię - rozwiązania zarazem architektoniczne i teatralno-filmowe: przesuwana w piwnicy szafa (jak kotara, a więc wyraźna granica między przestrzenią udawania a „kulisami” - miejscem rzeczywistej walki na śmierć i życie), zasuwane 
drzwi garażu (wyraźnie oddzielające czas pożegnania przez panią Kim wyjeżdżających na biwak pracodawców od tego, co za chwilę wydarzy się w samym domu), wreszcie ogromne okno salonu. W tym ostatnim przypadku mamy już do czynienia z wyraźnie otwartą sceną: wnętrze obserwujemy z ogrodu bądź, odwrotnie, w scenach rozgrywanych w salonie podziwiamy widok na ogród. W ten sposób przestrzeń domu staje się przestrzenią gry, udawania, fałszywych tożsamości i przyjmowanych ról społecznych.

Z taką propozycją jest skorelowane jeszcze jedno, rozumiane nieco węziej, pojęcie g ry, również wyrastające z przestrzennych analiz filmu. Chodzi tu o grę planszową, terenową lub komputerowa, w której uczestnicy krążą po „planszy”, poruszają się w przód i w tył, do góry i w dół, wypychają się z zajmowanych miejsc, przejmują „pozycję”. Oprócz wspomnianej sceny ucieczki Ki-taeka można tu przypomnieć, że na samym początku wizyty Ki-woo w domu państwa Park służąca, przyjmując gościa, jednocześnie zbiera zabawki pozostawione przez najmłodsze dziecko - strzały indiańskie. To ważna zapowiedź motywu „zabawy w Indian", ale także dynamiczny moment znaczący i inicjalny: gosposia porusza się $\mathrm{w}$ domu i zbiera strzały-trofea, idealny porządek zostaje zmieszany z bałaganem, a powaga z zabawą.

Film Bonga - podobnie jak scenograficzno-architektoniczny artefakt wykonany na jego potrzeby - ma dokładną, przemyślaną, struktura lną bu d ow ę. Na kilka elementów tej budowy udało się, mam nadzieję, już wskazać. Dodatkowo listę chwytów scenariuszowych i reżyserskich można poszerzyć o szereg rymów, nawrotów oraz fabularnych i wizualnych paralelizmów (brzoskwinie jako lejtmotyw; wybijająca kanalizacja u państwa Kim oraz wymiotująca w tym samym czasie w schronie gosposia; ciosy zadawane nożem kolejnym ofiarom podczas przyjęcia urodzinowego).

Wszystkie te zabiegi, mistrzowsko zrealizowane i z taką intensywnością wskazywane przez recenzentów i wideoeseistów ${ }^{28}$, decydują o autotelicznym charakterze filmu. Realizacyjna precyzja Bonga nie jest tu bowiem celem, lecz tematem. Szczególnie wyraźnie przejawia się to choćby w autorskiej ironii (wspomniane wypowiedzi chłopaka o „metaforyczności”), ale także w kwestiach dotyczących procesu tworzenia historii oraz samego aktu opowiadania. Dobrze ilustruje to ostatnia scena filmu. Wcześniej jednak Ki-taek w rozmowie z synem o planach życiowych przekonuje go, że brak planu nigdy nie zawodzi: Kiedy masz plan, życie go weryfikuje. Bez planu nic nie może pójść źle. W zakończeniu chłopak powraca do tej życiowej rady, pla n u je i pisze - alfabetem Morse'a - w liście do ojca: kiedy kupię ten dom, wtedy wystarczy, że wejdziesz na górę... Oto możliwa konkluzja: dokładny plan, o którym wiemy, że życie może go zweryfikować (ponieważ to „tylko” marzenie), oraz "działanie" architektury w opowieści o zdarzeniach plan wypełniających.

${ }^{1}$ Poszukiwania (także internetowe) w tym zakresie warto rozpoczać od lektury ",tematycznego" numeru "Sight \& Sound" z marca $2020 \mathrm{r}$.

2 Por. P. Saramowicz, Film $w$ architekturze (Tschumi, Koolhaas i Libeskind), "Kwartalnik Filmowy" 1999, nr 28, s. 216.

${ }^{3}$ Por. E. Rewers, Ekran miejski, w: Pisanie miasta - czytanie miasta, red. A. Zeidler-Jani- szewska, Wyd. Fundacji Humaniora, Poznań 1997; E. Rewers, Pożegnanie z ekranem miejskim: ku "nowej prostocie", w: Wiek ekranów. Przestrzenie kultury widzenia, red. A. Gwóźdź, P. Zawojski, Wydawnictwo Rabid, Kraków 2002. Obserwowaną dziś tendencją jest choćby obecność w miejskiej przestrzeni reklamy filmów - już nie w postaci plakatów w kinowych gablotach czy na przystankach ko- 
munikacji publicznej, nawet nie $\mathrm{w}$ postaci billboardów, ale ogromnych, całościennych graffiti (może sobie na nie pozwolić na przykład tak znaczący producent seriali, jak Netflix).

${ }^{4}$ Por. A. Gwóźdź, Technologie widzenia, czyli media w poszukiwaniu autora: Wim Wenders, Universitas, Kraków 2004, s. 78.

${ }^{5}$ W. Wenders, Pejzaż miejski, tłum. M. Behlert, w: Europejskie manifesty kina. Od Matuszewskiego do Dogmy. Antologia, wybór, wstęp, oprac. A. Gwóźdź, Wiedza Powszechna, Warszawa 2002.

${ }^{6}$ E. Rewers, Światło i ekran, w: tejże, Post-polis. Wrowadzenie do filozofii ponowoczesnego miasta, Universitas, Kraków 2005, s. 125.

${ }^{7}$ Por. M. Saryusz-Wolska, Berlin. Filmowy obraz miasta, Wydawnictwo Rabid, Kraków 2007; E. Mazierska, Janusowe oblicze filmowego miasta, „Kwartalnik Filmowy” 1999, nr 28, s. 38-53; R. Koschany, Niewidzialne miasta? Przypadek filmu polskiego, w: Sztuka - kapitał kulturowy polskich miast, red. E. Rewers, A. Skórzyńska, Wydawnictwo Naukowe UAM, Poznań 2010.

${ }^{8}$ Por. A. Stasiak, Turystyka literacka i filmowa, w: Wspótczesne formy turystyki kulturowej, red. K. Buczkowska, A. Mikos v. Rohrscheidt, Wydawnictwo AWF, Poznań 2009; P. Kwiatkowska, Między Marienbadem a Monachium, czyli od obrazu do rzeczywistości i z powrotem, w: Nowa kinofilia: przestrzenie $i$ afekty, red. K. Kosińska, P. Kwiatkowska, Fundacja Mammal, Warszawa 2018.

${ }^{9}$ Por. K. Kosińska, Materialność wyspy. O set-jettingu $i$ "Człowieku z Aran" Roberta Flaherty'ego, w: Nowa kinofilia... dz. cyt., s. 41-56; G. Nadgrodkiewicz, Śladami Pani Dalloway. Peregrynacje literacko-filmowointernetowe a set-jetting, w: Nowa kinofilia, dz. cyt., s. 81-100.

10 Por. R. Stępowski, City placement. Miasto $w$ filmie. Film $w$ mieście, Wydawnictwo Roster, Rawa Mazowiecka 2017.

${ }^{11}$ Ze względu na ograniczone ramy artykułu jestem zmuszony tylko wskazać ten nadrzędny dla rozważań wątek, odsyłając czytelnika do stosownej literatury przedmiotu: T. Miczka, [współpr.] E. Ostrowska, Przestrzeń, w: T. Miczka, Słownik pojęć filmowych, t. 9, Wydawnictwo Uniwersytetu Śląskiego, Katowice 1998, s. 95-143; E. Ostrowska, Przestrzeń filmowa, Wydawnictwo Rabid, Kraków 2000; A.S. Dudziak, Antropologia przestrzeni $w$ filmie fabularnym, Wydawnictwo UMCS, Lublin 2000; B. Kita, Między przestrzeniami. O kulturze nowych mediów, Rabid, Kraków 2003.
${ }^{12}$ Por. R. Koeck, Cine-scapes. Cinematic Spaces in Architecture and Cities, Routledge, New York 2013.

${ }^{13}$ Por. B. Uspienski, Strukturalna wspólnota różnych rodzajów sztuki (na przykładzie malarstwa i literatury), tłum. Z. Zaron, w: Semiotyka kultury, wybór i oprac. E. Janus, M. R. Mayenowa, PIW, Warszawa 1975; E. Wiegandt, Powinowactwa przez kompozycję (w literaturze najnowszej), w: tejże, Niepokoje literatury. Studia o prozie polskiej XX wieku, Wydawnictwo WBPiCAK, Poznań 2010.

${ }^{14}$ J.E. Cirlot, Słownik symboli, tłum. I. Kania, Wydawnictwo Znak, Kraków 2000, s. 112 (s.v. ,dom").

${ }^{15}$ Por. W. Toporow, Miasto i mit, wybór, tłum., wstęp B. Żyłko, słowo/obraz terytoria, Gdańsk 2000.

${ }^{16}$ Wśród odmian gatunkowych horroru Noël Carroll wyróżnia opowieści o nawiedzonym domostwie (haunted house); por. N. Carroll, Filozofia horroru albo paradoksy uczuć, tłum. M. Przylipiak, słowo/obraz terytoria, Gdańsk 2004, s. 169.

${ }^{17}$ Ł. Mańkowski, Kalejdoskop społecznego niepokoju, https://kulturaliberalna.pl/2019/09/24/lukasz-mankowski-kalejdoskop-spolecznego-niepokoju-parasite-bong-joon-ho/ (dostęp: 29.12.2019).

${ }^{18}$ C. O'Falt, Building the 'Parasite' House: How Bong Joon Ho and His Team Made the Year's Best Set, https://www.indiewire.com/2019/10/parasite-house-set-design-bong-joonho-1202185829/ (dostęp: 05.01.2020).

${ }^{19} \mathrm{~J}$. Łotman, Zagadnienie przestrzeni artystycznej w prozie Gogola, tłum. J. Faryno, w: Semiotyka kultury, dz. cyt., s. 221; por. także J. Łotman, Problem przestrzeni artystycznej, tłum. J. Faryno, w: Studia z teorii literatury. Archiwum przekładów „Pamiętnika Literackiego", red. K. Bartoszyński, M. Głowiński, H. Markiewicz, t. II, Ossolineum, Wrocław 1988.

${ }^{20}$ J. Łotman, Semiotyka filmu, tłum. J. Faryno, T. Miczka, Wiedza Powszechna, Warszawa 1983, s. 165.

${ }^{21}$ Tamże, s. 187 (rozdział: Problemy semiotyki i tendencje kina wspótczesnego).

22 Tamże, s. 193.

${ }^{23}$ T. Miczka, [współpr.] E. Ostrowska, Przestrzeń, dz. cyt., s. 120.

${ }^{24}$ E. Ostrowska, Przestrzeń filmowa, dz. cyt., s. 37. Opracowana przez badaczkę kwestia narratywizacji przestrzeni filmowej wiele zawdzięcza artykułowi Narrative Space Stephena Heatha z 1976 r. (por. S. Heath, Narrative Space, "Screen” 1976, t. 17, nr 3). 
${ }^{25}$ Por. K. Irzykowski, Dziesiąta muza. Zagadnienia estetyczne kina, Filmowa Agencja Wydawnicza, Warszawa 1957, s. 47.

${ }^{26}$ Por. C. O'Falt, dz. cyt.

27 Tamże.
${ }^{28}$ Por. Nerdwriter, Parasite's Perfect Montage, https://www.youtube.com/watch?v=ma1rD 2OP85c\&fbclid=IwAR0zruxqDPnI4MnweO_SMTE6EtmDLsdNyXqHPWtN6_Y1IIz9oWufGnpcAw (dostęp: 06.01.2020).

\section{Rafał Koschany}

Profesor w Instytucie Kulturoznawstwa Uniwersytetu im. Adama Mickiewicza w Poznaniu. Specjalizuje się w teorii interpretacji, współczesnych teoriach interpretacji dzieł sztuki, semiotyce kultury, a także badaniach pogranicza literaturoznawstwa i filmoznawstwa. Jest autorem monografii Przypadek. Kategoria artystyczna $i$ egzystencjalna w literaturze i filmie (2006, wyd. II - 2016) i Zamiast interpretacji. Między doświadczeniem kinematograficznym a rozumieniem filmu (2017), licznych artykułów w czasopismach naukowych i rozdziałów w książkach oraz współredaktorem kilku publikacji zbiorowych (m.in. Musical. Poszerzanie pola gatunku, 2013).

\section{Bibliografia}

Cirlot, J. E. (2000). Słownik symboli (tłum. I. Kania). Kraków: Wydawnictwo Znak.

Dudziak, A. S. (2000). Antropologia przestrzeni w filmie fabularnym. Lublin: Wydawnictwo UMCS.

Gwóźdź, A. (2004). Technologie widzenia, czyli media w poszukiwaniu autora: Wim Wenders. Kraków: Universitas.

Heath, S. (1976). Narrative Space. Screen, 17 (3), ss. 68-112.

Irzykowski, K. (1957). Dziesiąta muza. Zagadnienia estetyczne kina. Warszawa: Filmowa Agencja Wydawnicza.

Kita, B. (2003). Między przestrzeniami. O kulturze nowych mediów. Kraków: Rabid.

Koeck, R. (2013). Cine-scapes. Cinematic Spaces in Architecture and Cities. New York: Routledge.

Koschany, R. (2010). Niewidzialne miasta? Przypadek filmu polskiego. W: E. Rewers, A. Skórzyńska (red.), Sztuka - kapitał kulturowy polskich miast (ss. 415-427). Poznań: Wydawnictwo Naukowe UAM.

Kosińska, K. (2018). Materialność wyspy. O set-jettingu i „Człowieku z Aran” Roberta Flaherty'ego. W: K. Kosińska, P. Kwiatkowska (red.), Nowa kinofilia: przestrzenie i afekty (ss. 41-56). Warszawa: Fundacja MAMMAL.

Kwiatkowska, P. (2018). Między Marienbadem a Monachium, czyli od obrazu do rzeczywistości i z powrotem. W: K. Kosińska, P. Kwiatkowska (red.), Nowa kinofilia: przestrzenie $i$ afekty (ss. 59-78). Warszawa: Fundacja MAMMAL.

Łotman, J. (1975). Zagadnienie przestrzeni artystycznej w prozie Gogola (tłum. J. Faryno). W: E. Janus, M. R. Mayenowa (red.), Semiotyka kultury (ss. 213-265). Warszawa: Państwowy Instytut Wydawniczy.

Łotman, J. (1983). Semiotyka filmu (tłum. J. Faryno, T. Miczka). Warszawa: Wiedza Powszechna.

Łotman, J. (1988). Problem przestrzeni artystycznej (tłum. J. Faryno). W: K. Bartoszyński, M. Głowiński, H. Markiewicz (red.), Studia z teorii literatury. Archiwum przekładów "Pamiętnika Literackiego" (t. 2, ss. 293-306). Wrocław: Ossolineum.

Mańkowski, Ł. (2019). Kalejdoskop społecznego niepokoju. KulturaLiberalna.pl. https://kulturaliberalna.pl/2019/09/24/lukasz-mankowski-kalejdoskop-spolecznego-niepokoju-parasite-bong-joonho/ 
Mazierska, E. (1999). Janusowe oblicze filmowego miasta. Kwartalnik Filmowy, 28, ss. 38-53.

Miczka, T., Ostrowska E. (1998). Przestrzeń. W: T. Miczka, Słownik pojęć filmowych (t. 9, ss. 95-143). Katowice: Wydawnictwo Uniwersytetu Śląskiego.

Nadgrodkiewicz, G. (2018). Śladami Pani Dalloway. Peregrynacje literacko-filmowo-internetowe a set-jetting. W: K. Kosińska, P. Kwiatkowska (red.), Nowa kinofilia: przestrzenie i afekty (ss. 81100). Warszawa: Fundacja MAMMAL.

O'Falt, C. (2019). Building the "Parasite" House: How Bong Joon Ho and His Team Made the Year's Best Set. IndieWire.com. https://www.indiewire.com/2019/10/parasite-house-set-design-bongjoon-ho-1202185829/

Ostrowska, E. (2000). Przestrzeń filmowa. Kraków: Wydawnictwo Rabid.

Rewers, E. (1997). Ekran miejski. W: A. Zeidler-Janiszewska (red.), Pisanie miasta - czytanie miasta (ss. 41-50). Poznań: Wydawnictwo Fundacji Humaniora.

Rewers, E. (2002). Pożegnanie z ekranem miejskim: ku „nowej prostocie”. W: A. Gwóźdź, P. Zawojski (red.), Wiek ekranów. Przestrzenie kultury widzenia (ss. 503-515). Kraków: Wydawnictwo Rabid.

Rewers, E. (2005). Post-polis. Wprowadzenie do filozofii ponowoczesnego miasta. Kraków: Universitas.

Saramowicz, P. (1999). Film w architekturze (Tschumi, Koolhaas i Libeskind). Kwartalnik Filmowy, 28, ss. 214-229.

Saryusz-Wolska, M. (2007). Berlin. Filmowy obraz miasta. Kraków: Wydawnictwo Rabid.

Stasiak, A. (2009). Turystyka literacka i filmowa. W: K. Buczkowska, A. M. von Rohrscheidt (red.), Wspótczesne formy turystyki kulturowej (ss. 223-265). Poznań: Wydawnictwo AWF.

Stępowski, R. (2017). City placement. Miasto w filmie. Film w mieście. Rawa Mazowiecka: Wydawnictwo Roster.

Toporow, W. (2000). Miasto i mit (tłum. B. Żyłko). Gdańsk: słowo/obraz terytoria.

Uspienski, B. (1975). Strukturalna wspólnota różnych rodzajów sztuki (na przykładzie malarstwa i literatury) (tłum. Z. Zaron). W: E. Janus, M. R. Mayenowa (red.), Semiotyka kultury (ss. 181-212). Warszawa: Państwowy Instytut Wydawniczy.

Wenders, W. (2002). Pejzaż miejski (tłum. M. Behlert). W: A. Gwóźdź (red.), Europejskie manifesty kina. Od Matuszewskiego do Dogmy. Antologia (ss. 349-363). Warszawa: Wiedza Powszechna.

Wiegandt, E. (2010). Powinowactwa przez kompozycję (w literaturze najnowszej). W: E. Wiegandt, Niepokoje literatury. Studia o prozie polskiej XX wieku (ss. 327-337). Poznań: Wydawnictwo WBPiCAK.

\author{
Keywords: \\ Bong Joon-ho; \\ Korean cinema; \\ architecture; \\ film narrative; \\ filmic space
}

\section{Abstract \\ Rafał Koschany \\ Architecture as Plot. Parasite by Bong Joon-ho}

Bong's Parasite is one of the most frequently awarded and best-reviewed films of 2019. Most journalists emphasized the critical and satirical tone of the work, directed against the economic stratification of South Korean society (and beyond). In this interpretation, however, a completely different dimension of the film is foregrounded, as signalled in the title formula "architecture as plot". The article consists of three parts. The first part includes preliminary theoretical findings concerning the category of film space and the relationship between the city (architecture) and film. The second part is an analysis of the semiotics of the city and the architecture of the house in which most of the action takes place. The third is devoted to reflections on architecture as a generator of subsequent events, which ultimately can be interpreted as a kind of pretending on stage or as a board game. As a conclusion, the author proposes to treat Bong's film as an autothematic statement, whose precise structure is not so much a goal, but a crucial topic. 